\title{
The Actor: The Key Determinator in Service Ecosystems
}

\section{Bård Tronvoll}

Business School, Inland Norway University of Applied Science, 2418 Elverum, Norway; bard.tronvoll@inn.no

Academic Editors: Francesco Polese, Luca Carrubbo and Orlando Troisi

Received: 4 February 2017; Accepted: 15 May 2017; Published: 19 May 2017

\begin{abstract}
Most descriptions of service ecosystems, which provide the foundations for value co-creation, focus on resource integration. In contrast, this article emphasizes the actor's key role as the foundation resource for value co-creation by looking at both societal- and individual-focused realms, which include the different social aspects of service ecosystems. Institutional arrangements, positions, schemas as mental models, and practices constitute the basis realms influencing the actor in his or her value creation. Societal- and individual-focused realms are dual structures that are in constant interaction. The interdependency of the realms is made apparent through the service ecosystem's ability to define how resources are understood, assessed, and applied. A thorough examination of the realms that influence the actors embedded in service ecosystems suggests that social forces guide and are guided by actors. This article offers six guidelines for understanding the vital role of actors in service ecosystems.
\end{abstract}

Keywords: service ecosystem; actor; foundation resource; institutions; mental model; practice

\section{Introduction}

In every ecosystem, there exists a key resource necessary for the ecosystem to create value and become viable. Holling [1] (p. 478) argues that "all ecosystems are controlled and organized by a small number of key plant, animal, and biotic processes that structure the landscape at different scales". The term keystone species has been used in ecological systems to emphasize the importance of certain animals, such as the sea star [2] or the sea otter [3]. A keystone species is one that has a significant impact on its community or ecosystem, and is "disproportionately large relative to its abundance" [4] (p. 609). Kotliar [5] has extended the term by arguing that key species perform roles not performed by other species or processes. However, the debate about what is a keystone species has been going on for a long time and is difficult to decide in practice. As a result, the term foundation resource is used to emphasize a resource that is abundant or dominant, and highly interactive in an ecosystem (based on [6]). In a service ecosystem, where business value is created, the actor is seen as a foundation resource because he/she possesses agency and can act freely and purposefully by using operant resources to act on other resources. Actors are the foundation resource in service ecosystems because they perform roles not performed by other resources or processes. It is therefore necessary to understand this driving force - the actor-to gain a deeper understanding of service ecosystems.

A systemic approach is vital to gaining a more thorough understanding of the actor and his or her efforts at value creation. The system of systems, the service ecosystem, is a complex, multifaceted, value-creating system that must be studied in action because of its built-in dynamics. A system's dynamics and complexity are mainly caused by its actors (e.g., customers, employees, or managers) and their social and market action. A service ecosystem provides the fundamental basis for actors' resource integration and value co-creation efforts through mutual service provision [7]. The concept of value co-creation implies that value is created through interactions with a set of resources guided by regulatory mechanisms embedded in a service ecosystem. Therefore, all actors—firms, employees, 
and customers-are resource integrators [8,9] embedded in a service ecosystem and its broader social system [10].

To understand the actor as a foundation resource in the service ecosystem, it is necessary to zoom out from dyadic relations to get the system perspective. Systems are made up of several components, the linkages between these components, and an environment [11,12]. General systems theory emphasizes an open, socially constructed, dynamic system that can be theoretically decomposed into: (1) the actors (social and economic market participants); (2) linkages and networks of actors (the social and collective relations); and (3) environment or context (boundaries, social, and market conditions through institutions and institutional arrangements).

Actors co-create value based on their individual perceptions and links to other actors through their network as well as through the embedded service ecosystems. In this complex, multifaceted environment, actors operate continually at a crossroads of different societal and individual realms. These realms continually and dynamically influence the actor, and are at the same time influenced by the actor. The societal and individual realms are embedded in the service ecosystem, which is co-created by the actors through recursive, reciprocal processes. This recursive value creation process is similar to Giddens's $[13,14]$ structuration process (duality of structures). Structuration forms institutions and actors' positions and enables or inhibits actors in mutual service provision. Therefore, to understand the importance of an actor's actions, we need to decompose the service ecosystem's components and characteristics and explore the forces that influence value co-creation.

Using this conceptualization, we aim to spark further debate about the fundamental role of actors in service ecosystems by proposing a framework that emphasizes the critical nature of their role and their efforts to co-create value. This framework is expressed through the societal and individual realms that influence actors' efforts in service ecosystems. The following section outlines the theoretical framework of this article and describes a service ecosystem and its components. Next, we discuss the proposed framework in further detail. Finally, we offer six principles that provide a better understanding of the actor's role in service ecosystems.

\section{Theoretical Framework}

The systemic approach to academic marketing is rooted in social and living systems perspectives from the late 1950s (e.g., [15-17]). The development of systems theory [18,19] provided a theoretical foundation for studying systems as integrated wholes, focusing on the arrangement of parts and the relationship between them. Systems theory emphasizes interdependencies across parts, engaged actors, and interactions within a larger environment. Systems can qualitatively acquire new properties through emergence, which may entail continuous evolution [19,20]. Sheth, Gardner, and Garrett [21] argue that a systemic approach provides a more holistic, complete view of marketing and value creation. Systems theory $[18,19]$ allows researchers to include and define a wide range of resources, activities, and interactions, which affect market exchanges and value creation. As a result, a systemic view of market exchanges has attracted great interest [22].

In a business setting, value-creating systems are described in some of the following ways: organized behavior systems [23]; value chains [24]; value networks [25]; value constellations [26]; business networks [27]; marketing systems [28]; service systems [29]; service ecosystems [30]; and viable systems [31].

The rationales for these descriptions create two distinct research avenues: (1) value created for the actor (viewing the actor as exogenous to the system), where value is embedded in units of output, described by product attributes, and designed through product development and manufacturing [32,33]; and (2) value that is co-created with the actor (viewing the actor as endogenous to the system), where value is exposed by or utilized in use $[7,8,23]$. Hints of this more recent rationale appeared in Alderson's [23] argument that a collection of components cannot form a value-creating system in and of itself; a set of appropriate, interrelated principal concepts or functions must structure the system. For example, a behavioral system includes actors, interactions, and resources that are 
shaped by human behavior. Actors influence the system and the integration of business activities and resources. Bagozzi [34] (p. 78) emphasizes the social context, describing an exchange system as a "set of social actors, their relationships to each other, and the endogenous and exogenous variables affecting the behavior of the social actors in those relationships." The concept of a value network implies that all firms are embedded in complex systems $[27,35,36]$ where actors play critical roles in the formation and evolution of business relationships and networks.

Normann and Ramírez [26] introduce the value constellation; they frame service firms as inter-organizational networks, which link firms, assets, and competencies in response to or in anticipation of new market opportunities. Spohrer et al. [29] (p. 72) use service science to propose the "service system," defined as "value co-creation configurations of people, technology, value propositions connecting internal and external service systems, and shared information (language, laws, measures, and methods)." Merz et al. [37] (p. 38) similarly refer to "resource integrators that collectively function as an interdependent ecosystem to mutually create value, as perceived phenomenologically (i.e., in context)." Finally, Lusch and Vargo [38] (p. 23) emphasize the dynamic aspect of these concepts, defining a service ecosystem as "a relatively self-contained, self-adjusting system of resource integrating actors connected by shared institutional arrangements and mutual value creation through service exchange."

Emerging interest in service ecosystems demands a conceptual and theoretical review of the different mechanisms that can explain the role of actors. This necessitates a social focus, as emphasized in structuration theory. Structuration theory is used to understand society and social systems; it can be used to describe systems and the actors that shape them $[13,14,39]$. This theory suggests that social life is shaped by social forces outside of the individual actor. It also affirms the duality of structure- the notion that structure or institutional properties are created by human action and shape future human action. Archer [40] places great emphasis on what she terms "inherited" structures in her morphogenetic approach and uses them to form the basis for "structural conditioning." According to Archer, structures are the outcomes of past agency and may emerge over time to become relatively autonomous, durable conditions of action, which is how actors come to know and use them.

According to our research rationale, value is co-created with actors, which emphasizes their vital role. Specifically, in action, service ecosystems are created by the activities and interactions of actors who operate using the available resources in a particular business context. Interactions are, first and foremost, social encounters; as Czepiel et al. [41] argue, a service encounter is inherently a social interaction between human beings. Orlikowski [42] (p. 405) indicates that "a structurational perspective is inherently dynamic and grounded in ongoing human action."

\section{The Actor}

A long research tradition has emphasized the importance of human resources, including Adam Smith's identification of "the acquired and useful abilities" of individuals as a source of "revenue or profit" [43] (pp. 213-214). Humans possess knowledge, skills, and other resources that can be leveraged for self-benefit or to benefit other actors. Vargo and Lusch [7] refer to the process of using competencies to benefit other actors as "service", a state that prompts the other party to reciprocate by applying its own competencies. Service-dominant (S-D) logic implies that value is co-created through activity and thus points to the primacy of human resources [44]. The actor is knowledgeable—capable of using his or her structural capabilities to interact in creative or innovative ways and thereby to co-create value [45]. Other resources available to actors, such as economic resources, may be equally symbolic influences (the capacity to define and legitimize institutions, rules, and values) or can influence position in the service ecosystem (access to and positioning in important networks) [39,46]. Consequently, actors are foundation resources in the service ecosystem surrounded by complexes of belief and practice, which are crucial to service provision.

Humans are social actors who continuously reflect on their actions and practices using their own schemas and mental models [13]. Social actors understand how society works and may even be aware 
of sociological accounts of social behaviors that can influence their own perceptions. Giddens [13] (p. 250) argues that "every member of a society must know [ ... ] a great deal about the workings of that society by virtue of his or her participation in it." Similarly, Granovetter [47] (p. 487) suggests that "actors do not behave or decide as atoms outside a social context, nor do they adhere slavishly to a script written for them by the particular intersection of social categories that they happen to occupy. Their attempts at purposive action are instead embedded in concrete, ongoing systems of social relations." Most often, the actor is driven by a desire to achieve a particular value, which connects to motivation and meaning. Whereas "social systems are regularized practices that lack reason, purpose, or needs and are incapable of adaptation" [13] (p. 7), actors possess these attributes and can engage in adaptive responses. Thus, purpose and intent become points of articulation between structure and human agents $[13,48]$. Furthermore, the intended outcomes of purposive action are always relatively desirable to the actor, even if they seem axiologically unappealing to an outside observer [49].

At the center of every service ecosystem is an actor who operates on and integrates various available resources, guided by mechanisms of beliefs and norms, in order to co-create value. As part of this value co-creation effort, the actor faces various forces standing at the intersection or crossroads of influencing realms. We argue that this crossroads can be divided analytically into societaland individual-focused realms, as illustrated in Figure 1. At this crossroads, the two dimensions appear to be a recursive duality, which demands the actor's attention. The first dimension, described as a societal-focused realm, imposes structure-a set of regulatory mechanisms-that enable or inhibit the actor's value co-creation and provide a foundation for his or her position in the service ecosystem. The second dimension, the individual-focused realm, is based on agency: the actor is knowledgeable and purposive, using his or her cognition through schemas to integrate resource and form practices (e.g., mental models and practices). The schema concept is a general mental model (a set of schemas), which can store individual understanding of value creation and practices that reflect value creation efforts.

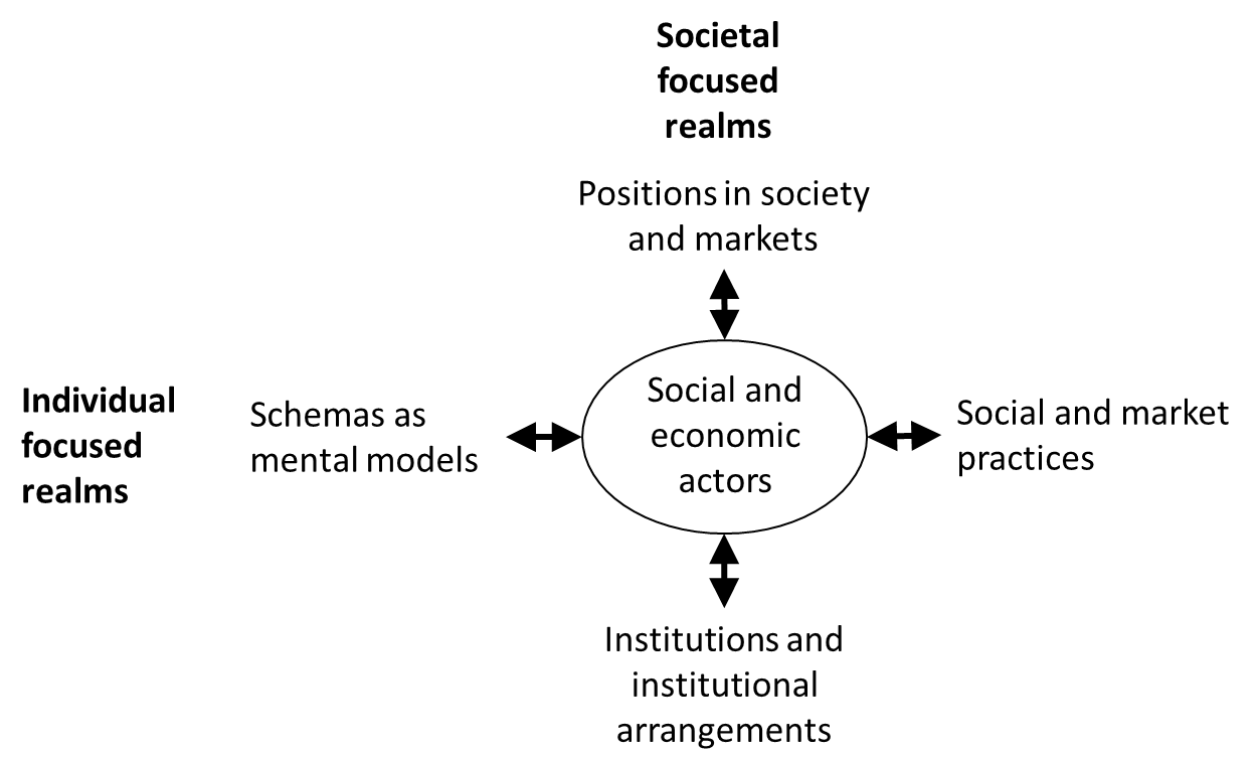

Figure 1. Societal-focused and Individual-focused realms influencing the actor.

Embedded in the four realms, individual action realizes institutional order through schemas and mental models, expressed by day-to-day actions. These schemas and day-to-day actions occur within service ecosystems that presume an underlying set of resources to facilitate the actor's engagement in particular practices and to support his or her corresponding position in the system. This resource integration process forms and is formed by institutions and institutional arrangements in continuous interactions. Actors' schemas and mental models simultaneously influence their understanding of 
reality; their actions confirm or challenge institutional arrangements and the positions the actors possess in the service ecosystem. At this crossroads, multiple societal levels of analysis (micro, meso, and macro) are layered within the embedded systems. These systems contain contradictory institutional arrangements, which may accommodate multiple agencies, nested in each higher structuring action and within each lower level.

\section{Societal-Focused Realms}

Societal-focused realms emphasize the social order that is applied in the market and society, and which guides the actor's value co-creation. In societal realms, actors are understood as social interpreters, carriers, and enactors of identities and meaning [50]. The societal-focused realms contain all forces that the actors are influenced by, the collective actions performed by groups, societies, and their embedded beliefs and norms. Regulatory mechanisms, such as institutions (beliefs, norms, rules, etc.) and institutional arrangements (interdependent assemblages of institutions) are the basic conditions that enable individuals to interact with and use other resources [51]. The efforts of these collective actions are institutionalized through the entrenchment of institutional arrangements. Institutional arrangements provide shared meaning that makes social life coherent through the creation of social identities and reinforcement of the service ecosystem's hierarchy [52], which delineates categories of actors and defines the cognitive schemas that govern actions $[53,54]$. Institutions, institutional arrangements, and service ecosystems refer to societal-focused realms, a historical accumulation of beliefs, norms, power, and interests constructed by individuals. Ultimately, these realms become dissociated from any one individual because they generate an institutionalized social order with a longer duration than any one actor or action, manifested through social positions.

\subsection{Institutions and Institutional Arrangements}

An institution is a social structure that is constructed according to the collective actions of actors in a constrained environment and is continuously altered over time [55-57]. Institutions are "a set of rules governing interpersonal governance" [58] (p. 70) that guide actors' value co-creation and assessments [51]. Institutions are not owned or possessed by a single actor; rather, they are shared by a larger group or society. Sewell [39] (p. 17) claims that institutions are "transposable procedures applied in the enactment of social life." Institutions guide actions through norms and rules, while resources empower actions [14]. Scott [57] has operationalized institutions into three broad sets and the corresponding legitimacy concerns in institutional environments: cognitive, regulative and normative. Cognitive institutions include widely shared social knowledge and the schemas, frames, and stereotypes used by major constituents in a particular environment. Regulative institutions have the capacity to establish and enforce formal rules and laws and, if necessary, impose sanctions. Normative institutions form the infrastructure of society and introduce prescriptive and evaluative dimensions into social life.

Institutional arrangements (sometimes referred to as institutional logics) provide the organizing principles for a field, industry, or larger social group [59]. They are described as "the belief systems and related practices" [57] (p. 139) that "define the content and meaning of institutions" [60] (p. 631). Institutional arrangements link institutions and actions. Haveman and Gualtieri [61] define institutional logics as systems of cultural elements (values, beliefs, and normative expectations) by which individuals, groups, and organizations make sense of, evaluate, and organize their everyday activities in time and space. Conversely, Vargo and Lusch [51] (p. 67-68) argue that "institutional arrangements are sets of institutions that are nested in multiple levels of social systems that guide actors in their actions and interactions."

Social interactions are guided by the different institutions to which actors consciously and subconsciously relate; institutions can only be recreated through interactions and practices. Gibbs [62] argues that social norms are rules that are shared by a group and contextually bind behavior according to a situation and the engaged actors' roles. Social norms help establish "a stable (but not necessarily 
efficient) structure to human interaction" [58] (p. 6). Institutions may come into conflict; which institution an actor chooses to follow, intentionally or unintentionally, depends on a range of factors. For a norm to exist, it must be enforced [63]. Within a service ecosystem, different norms and expectations prescribe and proscribe action.

\subsection{Position}

Position refers to the actor's perceived standing in a system hierarchy. The actor's position depends not only on objective characteristics, but on other socially constructed issues, such as actors' experiences, perceptions, comparisons, and visions for the future [64]. The actor's position in a service ecosystem and the wider social system determines his or her access to resources. All human interaction is, according to Giddens [14], inextricably composed of structures of signification (meaning), domination (power), and legitimation (moral framework), which constitute social modalities. Position is enforced by the actor's control over resources (domination) and accepted norms (legitimation); this provides meaning (signification) in the service ecosystem and society. Actors exercise power, enforced by their positions, by drawing on available resources to recreate structures of control. Giddens [14] (p. 16) views power as relational: "all forms of dependence offer some resources whereby those who are subordinate can influence the activities of their superiors." Giddens views power as capability manifested in action rather than as an act (e.g., making others do things against their will) or a stockpile of capital (e.g., land or money). We therefore link power to position in the service ecosystem and understand it as the ability to mobilize structures (resources and institutions) to achieve a purpose.

The actor's position usually reflects his or her ability to control and access resources and it has a relatively stable base, whereas roles are more contextual and volatile. Positions may evoke roles, particularly learned and institutionalized social roles. When a specific social context arises, a position is evoked and implemented. In service ecosystems, position is grounded in the "arenas of power relations," where some actors occupy "more advantaged positions than others" [65] (p. 355). Since a service ecosystem is established through structuration that suits the most powerful actors, their values and beliefs are reflected in the institutional logic $[56,66]$.

\section{Individual-Focused Realms}

Individual-focused realms emphasize the relationship between actors' schemas and mental models (a set of cognitive assumptions) and their practices (a set of actions), including how the realms support and facilitate value co-creation.

\subsection{Schemas}

Schemas are representations of knowledge and information-processing mechanisms, as well as mechanisms that simplify cognition (DiMaggio 1997). Bern [67] (p. 355) defines a schema as "a cognitive structure, a network of associations that organizes and guides an individual's perception." Schemas are the foundations of mental models; therefore, they are vital to decision-making and value co-creating efforts. Bern [67] and Neisser [68] argue that individual perception emerges through constructive cognitive processes, in which perception is created through interactions between new information and pre-existing schemas. A set of schemas constitutes the mental models and underlies actors' practices. Reflection-on-action, which takes place after practice, allows access to actors' implicit representations and mental models [69,70]. Jones et al. [69] (p. 46) describe mental models as "personal, internal representations of external reality that people employ to interact with the world around them." Mental models are used to reason and make decisions, can form the basis of individual action, and provide a mechanism through which new information is filtered and stored. Mental models enable actors to traverse and orient themselves within a system [71], and guide the interpretation of the past and present, as well as expectations for the future [72].

Based on schemas and mental models, sense-making expands the understanding of the internalization or adoption process to the service ecosystem; it explicitly presents an individual 
actor's role and how he or she co-creates value. Value co-creation is the basis of an actor's individually held mental model or perceptions [73]. Sense making in a service ecosystem is "highly selective and enables the individual to impose structure and meaning onto the vast array of incoming stimuli" [67] (p. 355). The process involves creating a coherent account of the service ecosystem by categorizing activities, interactions, relations, etc., and by applying patterns to connect to the past or anticipate the future [74]. Sense making is the basis of evaluation, which involves judging the value of co-creation or how actors integrate resources [75].

\subsection{Practices}

A practice is "a routinized type of behavior, which consists of several elements, interconnected to one other." [76] (p. 49) Practices involve rules and procedures for making meaning that function as cultural blueprints for action and interpretation [77]. Over time, practices enable actors to coordinate their intentions, meanings, actions, and behaviors and explain how value and markets are co-created, integrated, and exchanged. In addition, practices assimilate communication and the interpretation of symbols and signs, which creates guidelines for normalizing practices and integrating different sets of resources to co-create value [78]. Practices are grounded, in part, in tacit representations of automated mental models that are seldom, if ever, questioned. Scholars describe three types of market practices-normative, representational, and integrative (including exchange)—which are being continually "performed" [78,79]. Normative practices are activities involved in forming normative expectations, representational practices are activities that shape images of markets and integrative practices are activities involved in the integration of market, public and private facing resources. The schemes and patterns that underlie practices help organize the "chaos" that actors encounter.

Institutions guide actions, though the relationship is not deterministic; actors still retain the capacity to act of their own free will. Thus, actors can choose to sustain or modify institutions through their actions $[13,14]$. It is necessary to emphasize that structuration theory does not reduce social life to a function of deterministic social forces; rather, it holds that agency, as represented by knowledgeable human agents and structures, occurs in a reciprocal relationship, whereby repetition creates and recreates structures and practices [80]. Structuration theory describes practices as the recurring, regularized actions of individuals within a social system, which create and recreate the system [81]. Thus, in structuration theory, practices have a dual nature. On the one hand, practices are reutilized activities that remain part of, enable, and constrain the social system. On the other hand, knowledgeable individuals, who have their own perceptions and experiences, carry out these practices [14].

\section{Discussion}

The past decades of research on value-creating systems have focused mainly on how to configure resources within the system. Scholars often propose a resource-based view or general systems theory to describe value-creating systems, without much consideration of the actor and his or her importance. The actor is a foundation resource in the service ecosystem because he or she is the driving force and plays a key role in creating value. This study uses structuration theory, a general S-D logic orientation, and a systems approach to analyze actors' roles in service ecosystems. The aim is to provide a better understanding of how actors influence and are influenced by different realms at the crossroads of institutions and institutional arrangements, positions, schemas as mental models, and practices.

An actor is a social being who draws on multiple resources and mechanisms to co-create value; this reinforces the fact that interactions and resource integration activities are primarily social interactions. To understand an actor's value co-creating behavior, we must examine the structure of societaland individual-focused realms. These realms guide the way that actors co-create value in a service ecosystem. Although an actor's competencies (knowledge and skills) are obviously of vital importance, these qualities cannot fully explain social interactions and activities. 
Norms, rules, and beliefs guide actors' actions when co-creating value within service ecosystems; they create and recreate the conditions that make social interactions and value co-creation possible. Although single or configured sets of resources are essential for value co-creation, the different realms represent the crossroads of properties in action, and guide actors to interact with and operate on resources. As Moran and Ghoshal [82] (p. 409) argue, "it is not resources per se, but the ability to access, deploy, exchange, and combine them that lies at the heart of value creation." Thus, realms are a prerequisite for an actor to act and operate on available resources. For an actor to efficiently and effectively create value, he or she must adapt to the current setting of the service ecosystem. Value creation efforts must, therefore, be nested within the institutional arrangements guiding the actor's behavior.

For an institution to be considered acceptable within a service ecosystem, it must be shared by other actors and supported by their cognitive understanding through familiar mental models. Once institutions are established, they tend to endure and resist change-even in the face of disconfirming information. When a structure is stable, institutions reflect actual practices; if a structure is unstable, institutions and actions are at odds and one or the other must change [83]. However, actors can break, make, or maintain institutions over time, particularly if social forces change [84]. Sewell's [39] description of how structures are recreated imagines an actor "reading" existing institutions and attempting to recreate structures. Different actors interpret and interact with existing schemas and mental models differently and therefore recreate or alter institutions. If institutions seem outdated or less useful for co-creating value, they may be challenged or replaced. The result is a complex blend of formal and informal constraints. In a service ecosystem, resources and institutions presuppose each other and become closely intertwined-one cannot exist without the other.

Different realms affect an actor's ability to integrate resources in the co-creation of value and to recreate the institutions that empower his or her activities. Resources have potential value [85]. To understand how this potential is realized, it is necessary to include the realms and their interdependencies. Explaining the structuring process may also illuminate the hidden links that connect an actor to resources, to one system or another, and/or to the broader social system. Based on this discussion, we propose six principles that explain how an actor is influenced in his or her value co-creation efforts. These are described below.

\subsection{Principle \#1: The Actor is the Foundation Resource and Key Determinator, Enabled or Constrained in His or Her Value Co-Creation Efforts by Societal-and Individual-Focused Realms Embedded in the Service Ecosystem}

As a foundation resource, an actor is a complex driver in the service ecosystem; his or her contribution to the system structure also depends on a range of other factors, including market practices and subsequent institutional arrangements. More importantly, the actor's actions depend on a range of purely subjective factors: beliefs and norms concerning social identity and its enactment through mental models result in appropriate market practices. Actors comprise a foundation resource as they possess agency and are able to use their cognition and competences to act on available resources. An actor as a foundation resource defines much of the structure of a service ecosystem by creating locally stable conditions for value creation, and by modulating and stabilizing fundamental service ecosystem processes. An actor's vital role as a key determinator in service ecosystems is influenced by the interdependencies of the different realms. A service ecosystem is, therefore, a resource- and institution-integrating system within which an actor co-creates value.

Value co-creation results from actors' efforts to integrate resources framed within the service ecosystem, as influenced by societal- and individual-focused realms. The actors' efforts to create value are enabled and constrained within the collective and social setting by the service ecosystem. 
6.2. Principle \#2: The Actor is Guided by a Set of Invisible Forces Expressed as Institutional Arrangements in Their Recursive Value-Creation Process, Which in Turn Influence Institutional Arrangements

Institutions guide the actor like a recipe or code of conduct, i.e., they direct the actor to what types of resources to integrate and how to operate on them. Most re-creations refer to everyday activities that confirm habits or procedures in the service ecosystem. Institutions are created and recreated as a result of actions and interactions, leading to institutional arrangements that guide service ecosystems. We assert that institutions and institutional arrangements define social contexts, determine how value is created and assessed, and shape what resources are used in the process. Value co-creation is a social process, based on the duality of structures, and which generates value for all engaged actors. However, from time to time, actors change or transform institutions by altering their behaviors, and thus creating new institutions. This implies that while actors are embedded in institutional arrangements, they are at least partially autonomous from them.

\subsection{Principle \#3: The Actor's Position in the Service Ecosystem is Enabled and Reinforced by the Institutional Arrangements}

Social norms are external control mechanisms [86] which influence the structures and processes within a service ecosystem. Institutional arrangements make sense of different situations and guide actors' responses (i.e., whether or not actions are acceptable), often through codes of conduct or scripts that delineate various activities and interactions. However, an actor's position in a service ecosystem dictates what resources he or she can access. For example, an actor at the top of a service ecosystem has greater access to and control of resources (he can access his own resources and the resources of positions below him). In other words, a higher position commands a greater number of resources and thus facilitates co-creation efforts. In the same vein, Hegel [87] argues that if someone defines me as a servant, then he defines himself as a master. However, if I do not accept the position of servant, he loses his position as master. Hegel shows that positions are socially constructed and thus determined by the actors' actions and the institutional arrangements. Consequently, institutional arrangements enforce positions in the service ecosystem. The first step in the struggle for recognition, represented by the position, is self-consciousness: the ability to abstract from one's particular position and view oneself as part of a community of individuals.

\subsection{Principle \#4: An Actor's Cognition Frames Schemas as Mental Models, Which are the Primary Basis for His or Her Value Co-Creation Efforts}

An actor's ability to exercise value co-creation depends on his or her purpose (e.g., meaning, attitude or energy), ability to communicate (e.g., inform or engage in dialog), and position (e.g., status or role). The actor's cognition is important because it guides the worldview and thus decides what kind of questions are asked and what type of solutions are preferred. This affects the resource integration process and value creation. Actors' schemas and mental models become a prerequisite for any action. An actor can exploit his or her capabilities to interact in creative or innovative ways and co-create value based on the applied mental models. In addition, partly internalized institutions may function as a map, reflected as mental models, for what to do and how to integrate available resources.

\subsection{Principle \#5: The Actor's Accumulated Actions Become a Practice that Reinforces or Modifies the Service Ecosystem}

Actors possess knowledge, skills, and the ability to transform practices and service systems through actions: "These practices take place in a structured social context within the social system and involve knowledgeable individuals" [88] (p. 353). Thus, value is context-specific, so different practices may require and foster different value-creation modes [10]. This is consistent with Schau et al. [89] (p. 41), who argue that "value is manifested in the collective enactment of practices." Thus, resource integration in the service ecosystem is expressed through actions, which are a function of the reciprocal relationship between structures and practices. Viewed from a systems perspective, systems are being 
continually performed through multiple actors' actions and practices. In other words, systems are continually formed and re-formed through the activities of social and economic actors.

6.6. Principle \#6: The Actor Can Play, Simultaneously or in Sequence, Multiple Roles, Such as Facilitators, Modifiers, or Disruptors in the Service Ecosystem as Part of Their Value Co-Creation Efforts

Actors always create value as part of their resource integration efforts, although they can play different roles depending on the viability of the service ecosystem. The actor as a foundation resource can play different roles, either simultaneously or in sequence, depending on the state of the service ecosystem, the setting, and the value co-creation efforts. Consequently, value creation is reflected in the different roles that the actor undertakes as part of resource integration. For example, if an ecosystem needs changes, the actor as a foundation resource plays the role of modifier. In other environments, the service ecosystem might need a facilitator or a disruptor to become viable.

\section{Conclusions and Future Research}

This article contributes to systems research by deepening our understanding of the actor's vital role in mutual service provision. Although service ecosystems have been discussed in relation to co-creation and context, a more in-depth analysis and conceptualization of actors' roles has been lacking to date. A service ecosystem is a prerequisite for and an enabler of the creation, recreation, and transition of structures; its resources can be activated to enhance value co-creation processes within a social context.

Existing systems research focuses mainly on resources and resource configuration, whereas current institutional arrangements research only examines culture and cognition. Our conceptualization of the actor's role in service ecosystems paves the way for more in-depth studies on the central role actors play by balancing societal- and individual-focused realms. To extend the understanding of actors' role as a foundation resource in the service ecosystem, future research should focus on how different realms are influencing the actor. Hence, future research should emphasize the separate realms but also the interdependencies and interplay between them.

The actor's role is realized and framed by institutional arrangements, which are constituted by the relationship between schemas and symbolic systems (i.e., mental models that give sense to identities and meaning) and practices (i.e., substantively embodied actions), a relationship mediated by the service ecosystem positions that form the basis for the actors' interactions with the world. Previous system or service research has not elaborated much on the importance of the actors' position in the service ecosystem. It seems important to get a deeper understanding of the actor's position in the service ecosystem because this position is often the base for accessing different kinds of resources. To get access to resources is a prerequisite for any resource integration and value co-creation efforts.

Institutions play a vital role in guiding, prioritizing, and assessing the use of different resources. Consideration of social aspects increases the complexity of service ecosystems, as exemplified by structuration theory. Usually, researchers investigate the interactions between resources or describe the outcomes of system interactions. Structuration theory offers more insight into what happens within an ecosystem when value is co-created and assessed. A wide range of forces influence how actors operate on resources and guide value co-creation. This calls for more research on the significance of institutions and institutional arrangements and their enabling or inhibiting effect on the actor value co-creation efforts.

Our research establishes key principles that facilitate the portrayal, description, and understanding of actors' vital roles in service ecosystems by focusing on value co-creation through the duality of the different realms. The six guidelines we outline here describe the key principles through which actors create and recreate service ecosystems.

Conflicts of Interest: The author declares no conflict of interest. 


\section{References}

1. Holling, C.S. Cross-Scale Morphology, Geometry, and Dynamics of Ecosystems. Ecol. Monogr. 1992, 62, 447-502. [CrossRef]

2. Paine, R.T. A note on trophic complexity and community stability. Am. Nat. 1969, 103, 91-93. [CrossRef]

3. Duggins, D.O. Kelp beds and sea otters: An experimental approach. Ecology 1980, 61, 447-453. [CrossRef]

4. Power, M.E.; Tilman, D.; Estes, J.A.; Menge, B.A.; Bond, W.J.; Mills, L.S.; Daily, G.; Castilla, J.C.; Lubchenco, J.; Paine, R.T. Challenges in the quest for keystones. BioScience 1996, 46, 609-620. [CrossRef]

5. Kotliar, N.B. Application of the New Keystone-Species Concept to Prairie Dogs: How Well Does It Work? Conserv. Biol. 2000, 14, 1715-1721. [CrossRef]

6. Soulé, M.E.; Estes, J.A.; Berger, J.; Del Rio, C.M. Ecological Effectiveness: Conservation Goals for Interactive Species Efectividad Ecológica: Metas de Conservación para Especies Interactivas. Conserv. Biol. 2003, 17, 1238-1250. [CrossRef]

7. Vargo, S.L.; Lusch, R.F. Evolving to a New Dominant Logic for Marketing. J. Mark. 2004, 68, 1-17. [CrossRef]

8. Vargo, S.L.; Lusch, R.F. Service-Dominant Logic: Continuing the Evolution. J. Acad. Mark. Sci. 2008, 36, 1-10. [CrossRef]

9. Edvardsson, B.; Kleinaltenkamp, M.; Tronvoll, B.; Mchugh, P.; Windahl, C. Institutional logics matter when coordinating resource integration. Mark. Theory 2014, 14, 291-309. [CrossRef]

10. Edvardsson, B.; Skålén, P.; Tronvoll, B. Service systems as a foundation for resource integration and value co-creation. In Special Issue-Toward a Better Understanding of the Role of Value in Markets and Marketing (Review of Marketing Research); Vargo, S.L., Lusch, R.F., Eds.; Emerald Group Publishing Limited: Bingley, UK, 2012.

11. Daellenbach, H.G. Systems and Decision Making: A Management Science Approach; Wiley: Chichester, UK, 1994.

12. Balzat, M. An Economic Analysis of Innovation: Extending the Concept of National Innovation Systems; Edward Elgar: Cheltenham, UK, 2006.

13. Giddens, A. Central Problems in Social Theory: Action, Structure and Contradiction in Social Analysis; Macmillan: London, UK, 1979.

14. Giddens, A. The Constitution of Society: Outline of the Theory of Structuration; Polity Press: Cambridge, UK, 1984.

15. Forrester, J.W. Industrial Dynamics: A Major Breakthrough for Decision Makers. Harv. Bus. Rev. 1958, 36, 37-66.

16. Bell, M.L. Marketing: Concepts and Strategy; Houghton Mifflin: Boston, MA, USA, 1966.

17. Cox, R. Distribution in a High-Level Economy; Prentice-Hall: Englewood Cliffs, NJ, USA, 1965.

18. Sterman, J.D. Business Dynamics: Systems Thinking and Modeling for a Complex World; Irwin McGraw-Hill: Boston, MA, USA, 2000.

19. Von Bertalanffy, L. General System Theory: Foundations, Development, Applications; Allen Lane: London, UK, 1971.

20. Mccarthy, I.P.; Tsinopoulos, C.; Allen, P.; Rose-Anderssen, C. New Product Development as a Complex Adaptive System of Decisions. J. Prod. Innov. Manag. 2006, 23, 437-456. [CrossRef]

21. Sheth, J.N.; Gardner, D.M.; Garrett, D.E. Marketing Theory: Evolution and Evaluation; Wiley: New York, NY, USA, 1988.

22. Vargo, S.L.; Lusch, R.F. It's all B2B ... and beyond: Toward a systems perspective of the market. Ind. Mark. Manag. 2011, 40, 181-187. [CrossRef]

23. Alderson, W. Dynamic Marketing Behavior: A Functionalist Theory of Marketing; Irwin: Homewood, IL, USA, 1965.

24. Porter, M.E. The Value Chain and Competitive Advantage; The Free Press: New York, NY, USA, 1985.

25. Coulson-Thomas, C. Customers, Marketing and the Network Organization. J. Mark. Manag. 1991, 7, $237-255$. [CrossRef]

26. Normann, R.; Ramírez, R. From Value Chain to Value Constellation: Designing Interactive Strategy. Harv. Bus. Rev. 1993, 71, 65-77. [PubMed]

27. Håkansson, H.; Snehota, I. Developing Relationships in Business Networks; Routledge: London, UK, 1995.

28. Layton, R.A. Marketing Systems-A Core Macromarketing Concept. J. Macromark. 2007, 27, $227-242$. [CrossRef] 
29. Spohrer, J.; Maglio, P.P.; Bailey, J.; Gruhl, D. Steps toward a Science of Service Systems. Computer 2007, 40, 71-77. [CrossRef]

30. Lusch, R.F.; Vargo, S.L.; Tanniru, M. Service, value networks and learning. J. Acad. Mark. Sci. 2010, 38, $19-31$. [CrossRef]

31. Barile, S.; Pels, J.; Polese, F.; Saviano, M. An Introduction to the Viable Systems Approach and Its Contribution to Marketing. J. Bus. Mark. Manag. 2012, 2, 54-78.

32. Kotler, P. Marketing Management; Prentice-Hall: Englewood Cliffs, NJ, USA, 1972.

33. Porter, M.E. Competitive Advantage: Creating and Sustaining Superior Performance; The Free Press: New York, NY, USA, 1985.

34. Bagozzi, R.P. Marketing as an Organized Behavioral System of Exchange. J. Mark. 1974, 38, 77-81. [CrossRef]

35. Håkansson, H. International Marketing and Purchasing of Industrial Goods: An Interaction Approach; Wiley: Chichester, UK, 1982.

36. Håkansson, H.; Ford, D. How should companies interact in business networks? J. Bus. Res. 2002, 55, 133-139. [CrossRef]

37. Merz, M.A.; He, Y.; Vargo, S.L. The Evolving Brand Logic: A Service-Dominant Logic Perspective. J. Acad. Mark. Sci. 2009, 37, 328-344. [CrossRef]

38. Lusch, R.F.; Vargo, S.L. Service-Dominant Logic: Premises, Perspectives, Possibilities; Cambridge University Press: Cambridge, UK, 2014.

39. Sewell, W.H. Theory of Structure: Duality, Agency, and Transformation. Am. J. Sociol. 1992, 98, 1-28. [CrossRef]

40. Archer, M.S. Realist Social Theory: The Morphogenetic Approach; Cambridge University Press: Cambridge, UK, 1995.

41. Czepiel, J.A.; Solomon, M.R.; Surprenant, C.F. The Service Encounter: Managing Employee/Customer Interaction in Service Businesses; Lexington Books: Lexington, MA, USA, 1985.

42. Orlikowski, W.J. Using Technology and Constituting Structures: A Practice Lens for Studying Technology in Organizations. Organ. Sci. 2000, 11, 404-428. [CrossRef]

43. Smith, A. An Inquiry into the Nature and Causes of the Wealth of Nations; Irwin: Homewood, IL, USA „1963/1776.

44. Lusch, R.F.; Vargo, S.L.; O’brien, M. Competing Through Service: Insights from Service-Dominant Logic. J. Retail. 2007, 83, 5-18. [CrossRef]

45. Edvardsson, B.; Tronvoll, B.; Gruber, T. Expanding understanding of service exchange and value co creation. J. Acad. Mark. Sci. 2011, 39, 327-339. [CrossRef]

46. Oakes, L.S.; Townley, B.; Cooper, D.J. Business Planning as Pedagogy: Language and Control in a Changing Institutional Field. Adm. Sci. Q. 1998, 43, 257-292. [CrossRef]

47. Granovetter, M.S. Economic Action and Social Structure: The Problem of Embeddedness. Am. J. Sociol. 1985, 91, 481-510. [CrossRef]

48. Vincent, J. Political Antropology: Manipulative Strategies. Annu. Rev. Antropol. 1978, 7, 175-194. [CrossRef]

49. Merton, R.K. The Unanticipated Consequences of Purposive Social Action. Am. Sociol. Rev. 1936, 1, 894-904. [CrossRef]

50. Zilber, T.B. Institutionalization as an Interplay between Actions, Meanings, and Actors: The Case of a Rape Crisis Center in Israel. Acad. Manag. J. 2002, 45, 234-254. [CrossRef]

51. Vargo, S.L.; Lusch, R. Institutions and axioms: An extension and update of service-dominant logic. J. Acad. Mark. Sci. 2016, 44, 5-23. [CrossRef]

52. Scott, W.R. Institutions and Organizations: Ideas and Interests; SAGE Publications: Thousand Oaks, CA, USA, 2008.

53. Ashforth, B.E.; Mael, F.A. Organizational identity and strategy as a context for the individual. In Advances in Strategic Management; Baum, J.A.C., Dutton, J.E., Eds.; JAI Press: Greenwich, CT, USA, 1996.

54. Berger, P.L.; Luckmann, T. The Social Construction of Reality: A Treatise in the Sociology of Knowledge; Penguin: London, UK, 1967.

55. Meyer, H.-D.; Rowan, B.; Meyer, H.-D.; Rowan, B. The New Institutionalism in Education; State University of New York Press: Albany, NY, USA, 2006.

56. Dimaggio, P.J.; Powell, W.W. The Iron Cage Revisited: Institutional Isomorphism and Collective Rationality in Organizational Fields. Am. Sociol. Rev. 1983, 48, 147-160. [CrossRef]

57. Scott, W.R. Institutions and Organizations; SAGE Publications: Thousand Oaks, CA, USA, 2001. 
58. North, D.C. Institutions, Institutional Change and Economic Performance; Cambridge University Press: Cambridge, UK, 1990.

59. Friedland, R.; Alford, R.A. Bringing Society Back in: Symbols, Practices, and Institutional Contradictions; The University of Chicago Press: Chicago, IL, USA, 1991.

60. Reay, T.; Hinings, C.R. Managing the Rivalry of Competing Institutional Logics. Organ. Stud. 2009, 30, 629-652. [CrossRef]

61. Haveman, H.A.; Gualtieri, G. Institutional logics. In Oxford Research Encyclopedia of Business and Management; Aldag, R., Ed.; Oxford University Press: New York, NY, USA, 2017.

62. Gibbs, J.P. Control: Sociology's Central Notion; University of Illinois Press: Urbana, IL, USA, 1989.

63. Horne, C. The Enforcement of Norms: Group Cohesion and Meta-Norms. Soc. Psychol. Q. 2001, 64, $253-266$. [CrossRef]

64. Lindemann, K. The Impact of Objective Characteristics on Subjective Socialposition. Trames J. Humanit. Soc. Sci. 2007, 11, 54-68.

65. Brint, S.; Karabel, J. The Diverted Dream: Community Colleges and the Promise of Educational Opportunity in America, 1900-1985; Oxford University Press: New York, NY, USA, 1991.

66. Fligstein, N. The Transformation of Corporate Control; Harvard University Press: Cambridge, MA, USA, 1990.

67. Bern, S.L. Gender schema theory: A cognitive account of sex typing. Psychol. Rev. 1981, 88, 354-364.

68. Neisser, U. Cognition and Reality; Freeman: San Francisco, CA, USA, 1976.

69. Jones, N.A.; Ross, H.; Lynam, T.; Perez, P.; Leitch, A. Mental models: An interdisciplinary synthesis of theory and methods. Ecol. Soc. 2011, 16, 46. [CrossRef]

70. Schön, D.A. Educating the Reflective Practitioner; Jossey-Bass: San Francisco, CA, USA, 1987.

71. Weick, K.E. Cognitive Processes in Organizations. In Research in Organizational Behavior; Staw, B.M., Ed.; JAI Press: Greenwich, CT, USA, 1979.

72. Harris, S.G. Organizational Culture and Individual Sensemaking: A Schema-based Perspective. Organ. Sci. 1994, 5, 309-321. [CrossRef]

73. Högström, C.; Tronvoll, B. The enactment of socially embedded service systems: Fear and resourcing in the London Borough of Sutton. Eur. Manag. J. 2012, 30, 427-437. [CrossRef]

74. Weick, K.E. Sensemaking in Organizations; SAGE: Thousand Oaks, CA, USA, 1995.

75. Lamont, M. Toward a Comparative Sociology of Valuation and Evaluation. Annu. Rev. Sociol. 2012, 38, 201-221. [CrossRef]

76. Reckwitz, A. Toward a Theory of Social Practices: A Development in Culturalist Theorizing. Eur. J. Soc. Theory 2002, 5, 243. [CrossRef]

77. Arnould, E.J.; Thompson, C.J. Consumer Culture Theory (CCT): Twenty Years of Research. J. Consum. Res. 2005, 31, 868-882. [CrossRef]

78. Vargo, S.L.; Akaka, M.A. Value Cocreation and Service Systems (Re) Formation: A Service Ecosystems View. Serv. Sci. 2012, 4, 207-217. [CrossRef]

79. Kjellberg, H.; Helgesson, C.-F. Multiple versions of markets: Multiplicity and performativity in market practice. Ind. Mark. Manag. 2006, 35, 839-855. [CrossRef]

80. Giddens, A. A Contemporary Critique of Historical Materialism; Macmillan: London, UK, 1981.

81. Berends, H.; Boersma, K.; Weggeman, M. The structuration of organizational learning. Hum. Relat. 2003, 56, 1035-1056. [CrossRef]

82. Moran, P.; Ghoshal, S. Markets, Firms, and the Process of Economic Development. Acad. Manag. Rev. 1999, 24, 390-412.

83. Maxwell, S. The Social Norms of Discrete Consumer Exchange: Classification and Quantification. Am. J. Econ. Sociol. 1999, 58, 999-1018. [CrossRef]

84. Koskela-Huotari, K.; Edvardsson, B.; Jonas, J.M.; Sörhammar, D.; Witell, L. Innovation in service ecosystems-Breaking, making, and maintaining institutionalized rules of resource integration. J. Bus. Res. 2016, 69, 2964-2971. [CrossRef]

85. Ketchen, D.J.; Hult, G.T.M.; Slater, S.F. Toward greater understanding of market orientation and the resource-based view. Strateg. Manag. J. 2007, 28, 961-964. [CrossRef]

86. Arndt, J. The Political Economy Paradigm: Foundation for Theory Building in Marketing. J. Mark. 1983, 47, 44-54. [CrossRef]

87. Hegel, G.W.F. Phenomenology of Spirit; Clarendon Press: Oxford, UK, 1977. 
88. Peters, L.D.; Gassenheimer, J.B.; Johnston, W.J. Marketing and the structuration of organizational learning. Mark. Theory 2009, 9, 341-368. [CrossRef]

89. Schau, H.J.; Muñiz, A.M.; Arnould, E.J. How Brand Community Practices Create Value. J. Mark. 2009, 73, 30-51. [CrossRef] 